\title{
The Influence of Wood Modification on Transfer Function of a Violin Bridge
}

\section{Utjecaj modifikacije drva na prijenosnu funkciju mosta za violinu}

\author{
Original scientific paper • Izvorni znanstveni rad \\ Received-prispjelo: 20. 10. 2019. \\ Accepted-prihvaćeno: 28. 4. 2020. \\ UDK: $630 * 835.2$ \\ https://doi.org/10.5552/drvind.2020.1966
}

\author{
C 2020 by the author(s). \\ Licensee Faculty of Forestry, University of Zagreb. \\ This article is an open access article distributed \\ under the terms and conditions of the \\ Creative Commons Attribution (CC BY 4.0) license.
}

\begin{abstract}
The violin bridge is an important component of a violin since it transmits the excitation forces from the string to the violin body. Depending on its structure, at a certain frequency spectrum, the bridge acts as a damper or amplifier of excitation forces, which depends on its transfer function. In the study, transfer functions in the range from $400 \mathrm{~Hz}$ to $7000 \mathrm{~Hz}$ in vertical directions of 3 bridges were measured. The bridges were made from maple wood and supplied by different manufacturers. The bridges were then thermally modified, and the transfer functions were measured again. To determine the influence of thermal modification on material properties, a sample of maple wood was also modified together with the bridges, and the modulus of elasticity and shear modulus before and after the modification were measured. Using Ansys software, a bridge was modelled by the finite element method, by which natural frequencies and transfer functions before and after the modification were calculated. It can be confirmed from the research that wood modification influences the bridge transfer function and that the finite element method can be used to determine the dynamic properties of the bridge by knowing the wood material properties and, therefore, to predetermine the transfer function of the violin bridge before its production.
\end{abstract}

Keywords: violin bridge; excitation; transfer function; finite element method; Ansys; wood modification

\begin{abstract}
SAŽETAK • Most na violini važan je dio toga glazbala jer prenosi pobudne sile iz žica u tijelo violine. Ovisno o svojoj strukturi, most na određenome frekvencijskom spektru djeluje kao prigušivač ili kao pojačalo pobudnih sila, što ovisi o njegovoj prijenosnoj funkciji. U istraživanju su mjerene prijenosne funkcije u rasponu od 400 do 7000 Hz u okomitim smjerovima na tri mosta. Mostove od javorova drva izradili su različitih proizvođači. Naknadno su mostovi toplinski modificirani i ponovo su izmjerene njihove funkcije prijenosa. Da bi se utvrdio utjecaj toplinske modifikacije na svojstva materijala, zajedno s mostovima modificiran je i uzorak javorova drva te su izmjereni modul elastičnosti $i$ modul smicanja prije i nakon modifikacije. Uz upotrebu softvera Ansys most je modeliran metodom konačnih elemenata, kojom su izračunane prirodne frekvencije i funkcije prijenosa prije i nakon modifikacije. Na temelju istraživanja može se potvrditi da modifikacija drva utječe na funkciju prijenosa mosta i da se metodom konačnih elemenata mogu odrediti dinamička svojstva mosta ako su poznata svojstva drvnog materijala. Prema tome, prijenosna funkcija mosta violine može se odrediti unaprijed, prije njegove izrade.
\end{abstract}

Ključne riječi: most za violinu; pobuda; prijenosna funkcija; metoda konačnih elemenata; Ansys; modifikacija drva

\footnotetext{
${ }^{1}$ Authors are assistant professor and professor at University of Ljubljana, Biotechnical Faculty, Department of Wood Science and Technology, Ljubljana, Slovenia.
} 


\section{INTRODUCTION}

\section{UVOD}

A violin is a musical instrument that has been known for centuries. The first violins were developed in Italy in the $16^{\text {th }}$ and $17^{\text {th }}$ centuries (Rossing, 2010) and reached a peak in the eighteen century in the hands of masters such as Antonio Stradivarius and Giuseppe Guarneri del Gesu of Cremona. Since then, many researchers have been involved in violin research. Some have explored the functioning of violins as a whole (Bissinger, 2008; Matsutani, 2018; Tai et al., 2018; Woodhouse, 2014), while others have studied the influence of various materials from which a violin is made and their surface treatment (Aditanoyo et al., 2017; Setragno et al., 2017), as well as the influence of damping and strings on the composition of the sound (Bissinger, 2004; Ravina, 2017).

A violin consists of several different components, whereby the bridge is definitely one of the more important parts. Its job is to transfer the excitation forces from the string to the top of the violin. When a violin player excites a string with a bow, it starts to oscillate at a frequency that depends on the string and can range from a few hundred to several thousand $\mathrm{Hz}$. In addition to the basic frequency, the string also oscillates with higher frequencies, called harmonic frequencies, which are integer multiples of the basic frequency. Depending on the structure, the violin bridge can thus act as a filter, by which at a certain frequency range the excitation forces can be transferred to the body of the violin, in some regions even amplified, while suppressed in another frequency range. Both frequency ranges can be identified by a transfer function, which can be measured from the bridge or calculated using various approaches. The importance of the bridge and its dynamic properties is also evidenced by numerous studies that have been done by various researchers, who have investigated both its shape and the material from which the bridge is made (Bissinger, 2006; Dujourdy et al., 2019; Gough, 2018; Jansson et al., 2016; Kabała et al., 2018; Matsutani, 2017; Woodhouse, 2005; Zhang et al., 2013). One of the approaches for improving the relevant properties of wood without the use of toxic chemicals is wood modification. There are several modifications available on an industrial scale. One of the most frequently used techniques is thermal modification. Based on the data of Welzbacher and Scheiding (2011), between 250,000 and $300,000 \mathrm{~m}^{3}$ of thermally modified wood is produced annually in Europe.
The purpose of the research was thus to study the influence of thermal modification of wood on the dynamic properties of a violin bridge and to determine their transfer function.

\section{MATERIALS AND METHODS 2. MATERIJALI I METODE}

Three bridges made from maple wood were taken (Figure 1). Bridges No. 1 and No. 2 were made by Aubert and bridge No. 3 was made by the Teller company. Bridge No. 2 was partially designed and adapted for use on a specific violin.

The violin bridges were clamped on a Kistler dynamometer type 9272 (Figure 2) and the transfer functions of the bridges were measured in the vertical direction. The bridges were excited on the upper side of the bridge with a harmonic force in the frequency range from 400 to $7000 \mathrm{~Hz}$, in $3 \mathrm{~Hz}$ steps by Tira TV51120 exciter. The excitation was gradual from minimum to maximum frequency, whereby each excitation frequency was paused for $150 \mathrm{~ms}$ for a steady state response to be established. The excitation force was measured with a Bruel \& Kjaser type 8200 piezo force transducer, which was inserted between the bridge and the exciter, and the response of the transmitted force was measured with a Kistler dynamometer. Both force signals were captured with a sampling frequency of $100 \mathrm{kHz}$ using a NI USB 6361 measuring card and LAbVIEW software, which was also used for the transfer function calculation. The transfer function of the experimental system was also measured, so that the Kistler dynamometer was directly excited, and the transfer function calculated from the measured excitation and response forces.

Bridge No. 1 was then modelled with Solidworks software, and a modal analysis was performed using finite element methods with Ansys software, whereby the natural frequencies of the bridge were calculated. The modulus of elasticity, shear modulus and Poisson ratios were taken from the literature (Kollmann, 1975) and adjusted relatively so that the calculated natural frequency of the main mode was in agreement with the natural frequency obtained from the measured transfer function. Material density and damping ratios, however, were determined from measurements of the mass and volume of the bridge, and from the measured transfer function, respectively, using the bandwidth method (Maia and Silva, 1998)
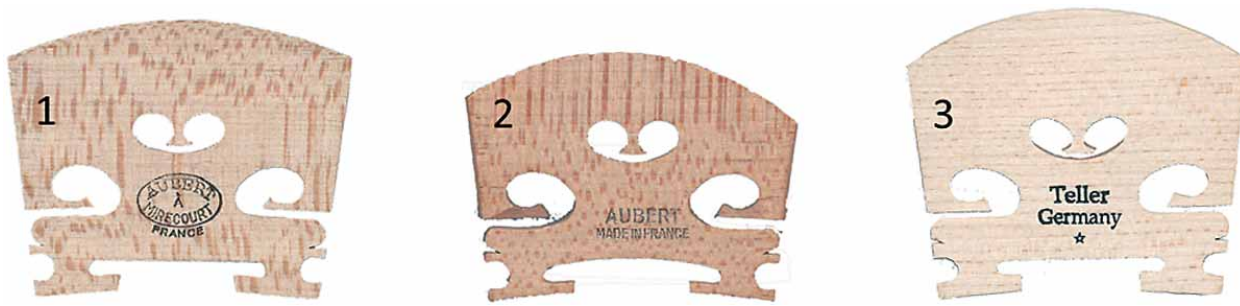

Figure 1 Tested violin bridges

Slika 1. Ispitivani mostovi za violinu 


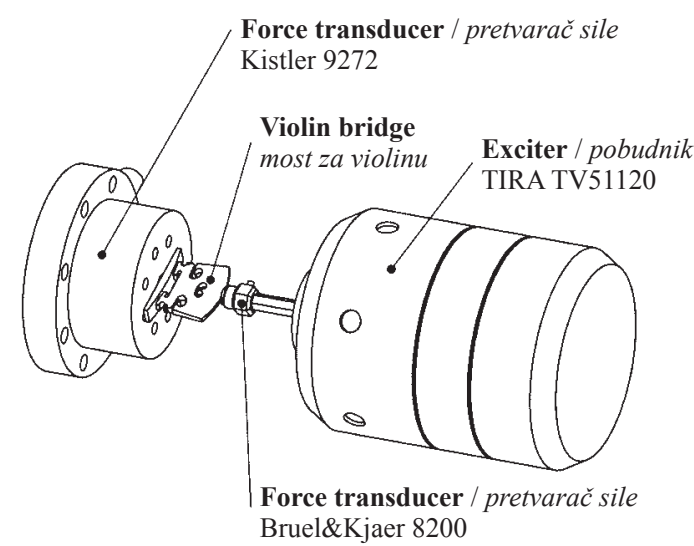

Figure 2 Testing of violin bridges

Slika 2. Ispitivanje mostova za violinu

$$
\xi=\frac{1}{2}\left(r_{2}-r_{1}\right)
$$

where $r_{2}$ and $r_{1}$ represent the ratios between the excitation and natural frequencies at the amplitude values of the transfer function which are by $\sqrt{2}$ lower than the maximum value for a given vibration mode, as shown in Figure 3.

Using the finite element method, a harmonic analysis was also performed, by which the transfer function was calculated. The clamped bridge was excited with a force of $1 \mathrm{~N}$ at different frequencies from 400 to 7000 $\mathrm{Hz}$, in steps of $10 \mathrm{~Hz}$, on 1/4 length of the bridge, so that asymmetric modes were also excited (Figure 4).

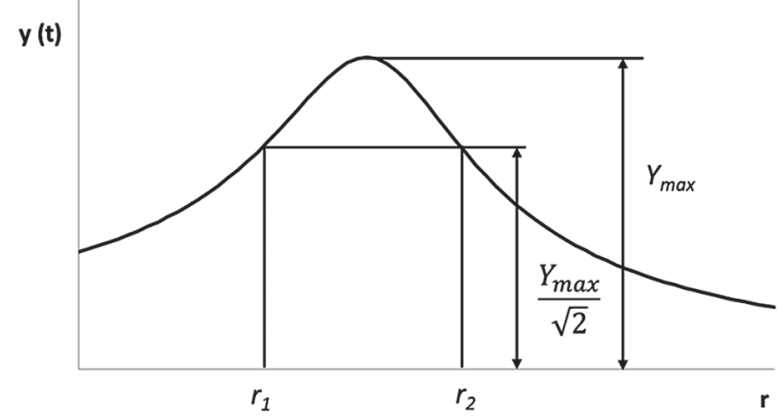

Figure 3 Damping ratio determination from transfer function using bandwidth method

Slika 3. Određivanje omjera prigušivanja iz funkcije prijenosa primjenom metode propusnosti

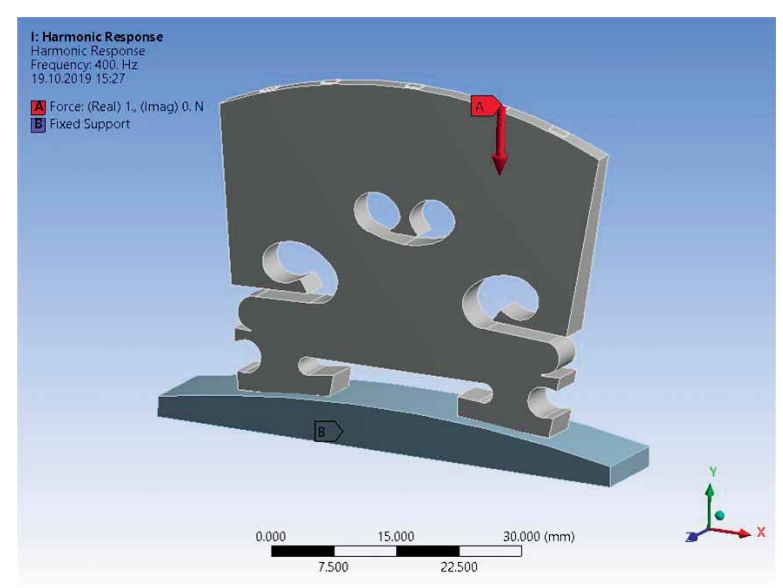

Figure 4 Finite element harmonic analysis setup Slika 4. Postavljanje harmonične analize konačnih elemenata

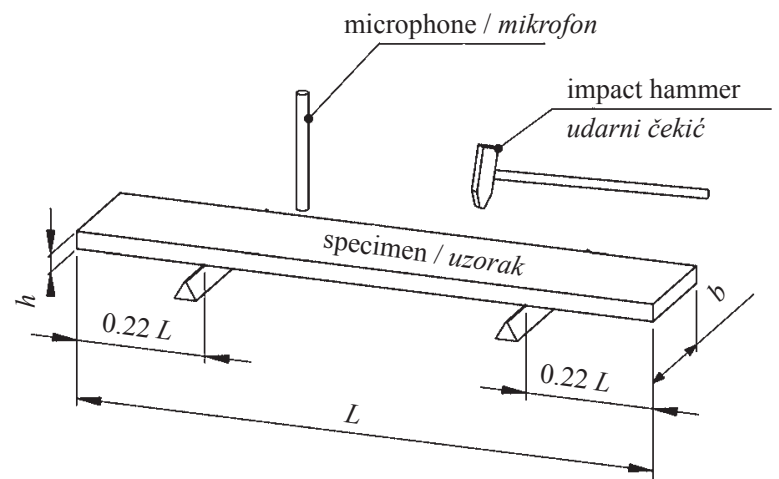

Figure 5 Experimental system for modulus of elasticity and shear modulus determination

Slika 5. Eksperimentalni sustav za određivanje modula elastičnosti i modula smicanja

In order to determine the effect of thermal modification on the material properties, a maple board with no visible defects and uniform growth was taken. From the board, 4 specimens with dimensions $300 \mathrm{~mm}$ $\times 80 \mathrm{~mm} \times 8 \mathrm{~mm}$ and $160 \mathrm{~mm} \times 25 \mathrm{~mm} \times 8 \mathrm{~mm}$ in $\mathrm{L}$ $\times \mathrm{R} \times \mathrm{T}$ and $\mathrm{R} \times \mathrm{L} \times \mathrm{T}$ directions, respectively, were cut and modified by the same procedure as the bridges.

Prior to the modification, the elastic modulus in longitudinal and radial directions and the shear modulus were measured, the samples being freely supported at distances of $0.22 \mathrm{~L}$ and $0.77 \mathrm{~L}$, and excited with a hammer (Figure 5) to vibrate freely at their natural frequencies.

The vibration of the samples was measured using a Bruel \& Kjaer Typ 4939 microphone, NI USB 6361 measuring card and LabVIEW software, with a sampling rate of $100 \mathrm{kHz}$. An FFT (Fast Fourier Transform) was made from the time signal and the natural frequencies $f$ for the various vibration modes were determined from the frequency spectrum. Modulus of elasticity $E$ and shear modulus $G$ were calculated using linear regression of the equation (Brancheriau and Bailleres, 2002)

$$
\begin{aligned}
& \frac{E}{\rho}-\frac{E}{K G}\left[Q F_{2}(m) 4 \pi^{2} \frac{A L^{4} f_{\mathrm{n}}^{2}}{I P_{\mathrm{n}}}\right]= \\
& =4 \pi^{2} \frac{A L^{4} f_{\mathrm{n}}^{2}}{I P_{\mathrm{n}}}\left[1+Q F_{1}(m)\right] \\
& Q=\frac{I}{A L^{2}} \\
& F_{1}(m)=\theta^{2}(m)+6 \theta(m) \\
& F_{2}(m)=\theta^{2}(m)-2 \theta(m) \\
& \theta(m)=m \frac{\tan (m) \tanh (m)}{\tan (m)-\tanh (m)} \\
& m=\sqrt[4]{P_{\mathrm{n}}}=(2 n+1) \frac{\pi}{2}, n \in N
\end{aligned}
$$

where $K$ is a constant that depends on the geometry of the cross-section (for rectangular, $K=5 / 6$ ), $I$ is the moment of inertia, $A$ is the cross-sectional area of the beam, $f_{n}$ is the $n$-th natural frequency. Parameters $m$, $F_{l}(m)$ and $F_{2}(m)$ are calculated on the basis of index $n$ for the $n$-th natural frequency. 


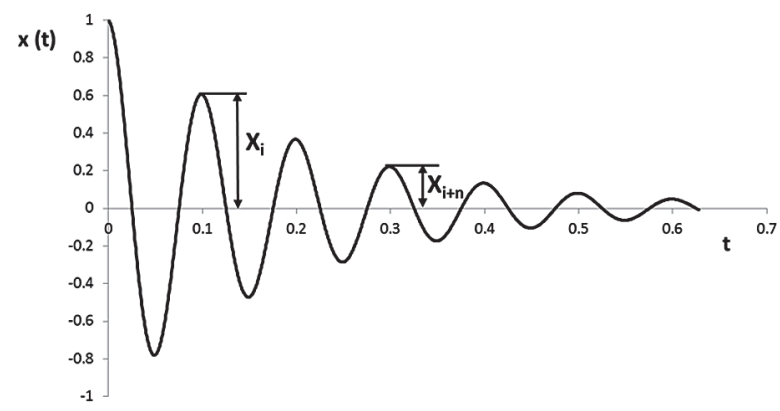

Figure 6 Determination of parameters needed for calculation of a logarithmic decrement of an underdamped system from a transient response

Slika 6. Određivanje parametara potrebnih za proračun logaritamske dekretacije prigušenog sustava iz prolaznog odziva

From the time recordings of specimen vibration, the material damping ratio $\xi$ was also determined by means of logarithmic decrement (Maia and Silva, 1998)

$$
\delta_{\mathrm{n}}=\ln \frac{X_{\mathrm{i}}}{X_{\mathrm{i}+\mathrm{n}}}=\frac{2 n \pi \xi}{\sqrt{1-\xi^{2}}}
$$

where $X_{\mathrm{i}}$ and $X_{\mathrm{i}+\mathrm{n}}$ are the amplitudes at locations $i$ and $i+n$, respectively, as shown in Figure 6 .

The bridges and maple specimens were then thermally modified. Thermal modification was performed according to the Silvapro ${ }^{\circledR}$ commercial procedure (Rep et al., 2012). Samples were thermally modified at $195{ }^{\circ} \mathrm{C}$. Prior to modification, samples were wrapped in $\mathrm{Al}$ foil to limit oxidation processes of wood. Al foil considerably slows down oxygen diffusion and consequently prevents unwanted polymer degradation. This solution proved to be effective for thermal modification of smaller specimens. Results are comparable to modification in an anoxic atmosphere. The time of modification at the target temperature was 3 hours and mass loss of the samples after modification was determined gravimetrically. After modification, samples were stored in the laboratory for a week $\left(23{ }^{\circ} \mathrm{C} ; 65 \%\right)$. After conditioning, both the transfer functions of the bridges and the material properties of the maple specimens were determined again. From the data, the influence of the thermal modification, in terms of the modification coefficient of wood properties, was calculated for the modulus of elasticity, shear modulus, density and damping ratios. Taking into account the changes due to the modification, modal and harmonic finite element analysis with the finite element method was performed again, and a comparison between the measured and calculated transfer functions of the bridges was made.

\section{RESULTS AND DISCUSSION}

\section{REZULTATI I RASPRAVA}

Table 1 shows the average values of the measured properties of maple specimens before and after modification. The modulus of elasticity in the longitudinal and radial directions increased by an average of $3.5 \%$ and $5 \%$, respectively, while shear modules in- creased by $1.2 \%$ and $17 \%$. The latter value is relatively large compared to other values and this may be due to measurement error. In contrast to the elastic properties, the density decreased by $3 \%$, and the damping ratios in longitudinal and radial directions by $15 \%$. Table 2 shows the properties of the material that were used in the modelling of the bridge by the finite element method, together with the correction factors obtained from Table 1. To calculate the change in all three values of the shear modulus, a single factor of 1.012 obtained from a comparison of the shear modulus of $G_{\text {LT }}$ was used, since the factor of 1.169 obtained from parallel samples seemed to be somewhat large and unrealistic when compared to the $G_{R T}$ module. Table 2 also shows the material density for bridge No. 1 and a damping factor of 0.029 and 0.016 for the unmodified and modified bridge, respectively, which are significantly higher than the damping values obtained from the maple samples, where the damping factors in longitudinal samples for unmodified and modified wood amounted to 0.0081 and 0.0069 , respectively, and for radial samples to 0.013 and 0.011 , respectively.

The measured transfer functions of the violin bridges are shown in Figures 7 to 9. The figures clearly

Table 1 Average modulus of elasticity, shear modulus, density and damping factors for unmodified and modified maple wood

Tablica 1. Prosječni modul elastičnosti, modul smicanja, gustoća i čimbenici prigušenja nemodificiranoga i modificiranog javorova drva

\begin{tabular}{|l|c|c|c|}
\hline & $\begin{array}{c}\text { Maple } \\
\text { unmodified } \\
\text { Nemodificira- } \\
\text { na javorovina }\end{array}$ & $\begin{array}{c}\text { Maple } \\
\text { modified } \\
\text { Modificirana } \\
\text { javorovina }\end{array}$ & $\begin{array}{c}\text { Modified / } \\
\text { unmodified } \\
\text { Modificirano / } \\
\text { nemodificirano }\end{array}$ \\
\hline$E_{\mathrm{L}}, \mathrm{MPa}$ & 13264 & 13727 & 1.035 \\
\hline$E_{\mathrm{R}}, \mathrm{MPa}$ & 1832 & 1923 & 1.050 \\
\hline$G_{\mathrm{TL}}, \mathrm{MPa}$ & 1117 & 1130 & 1.012 \\
\hline$G_{\mathrm{RT}}, \mathrm{MPa}$ & 346 & 405 & 1.169 \\
\hline$r, \mathrm{~kg} / \mathrm{m}^{3}$ & 592 & 574 & 0.970 \\
\hline$\xi_{\mathrm{L}}$ & 0.0081 & 0.0069 & 0.851 \\
\hline$\xi_{\mathrm{R}}$ & 0.0130 & 0.0111 & 0.853 \\
\hline
\end{tabular}

Table 2 Modulus of elasticity, shear modulus, density and damping factors for unmodified and modified maple wood used in the finite element method calculation for bridge No. 1 Tablica 2. Modul elastičnosti, modul smicanja, gustoća i čimbenici prigušenja nemodificiranoga i modificiranog javorova drva korišteni u proračunu metodom konačnih elemenata za most br. 1

\begin{tabular}{|l|c|c|}
\hline & $\begin{array}{c}\text { Unmodified } \\
\text { Nemodificirano }\end{array}$ & $\begin{array}{c}\text { Modified } \\
\text { Modificirano }\end{array}$ \\
\hline$E_{\mathrm{L}}, \mathrm{MPa}$ & 8300 & 8590 \\
\hline$E_{\mathrm{R}}, \mathrm{MPa}$ & 1262 & 1324 \\
\hline$E_{\mathrm{T}}, \mathrm{MPa}$ & 730 & 767 \\
\hline$G_{\mathrm{LR}}, \mathrm{MPa}$ & 1013 & 1024 \\
\hline$G_{\mathrm{RT}}, \mathrm{MPa}$ & 249 & 252 \\
\hline$G_{T L}, \mathrm{MPa}$ & 913 & 924 \\
\hline$\xi$ & 0.029 & 0.016 \\
\hline$\rho, \mathrm{kg} / \mathrm{m}^{3}$ & 560 & 520 \\
\hline
\end{tabular}




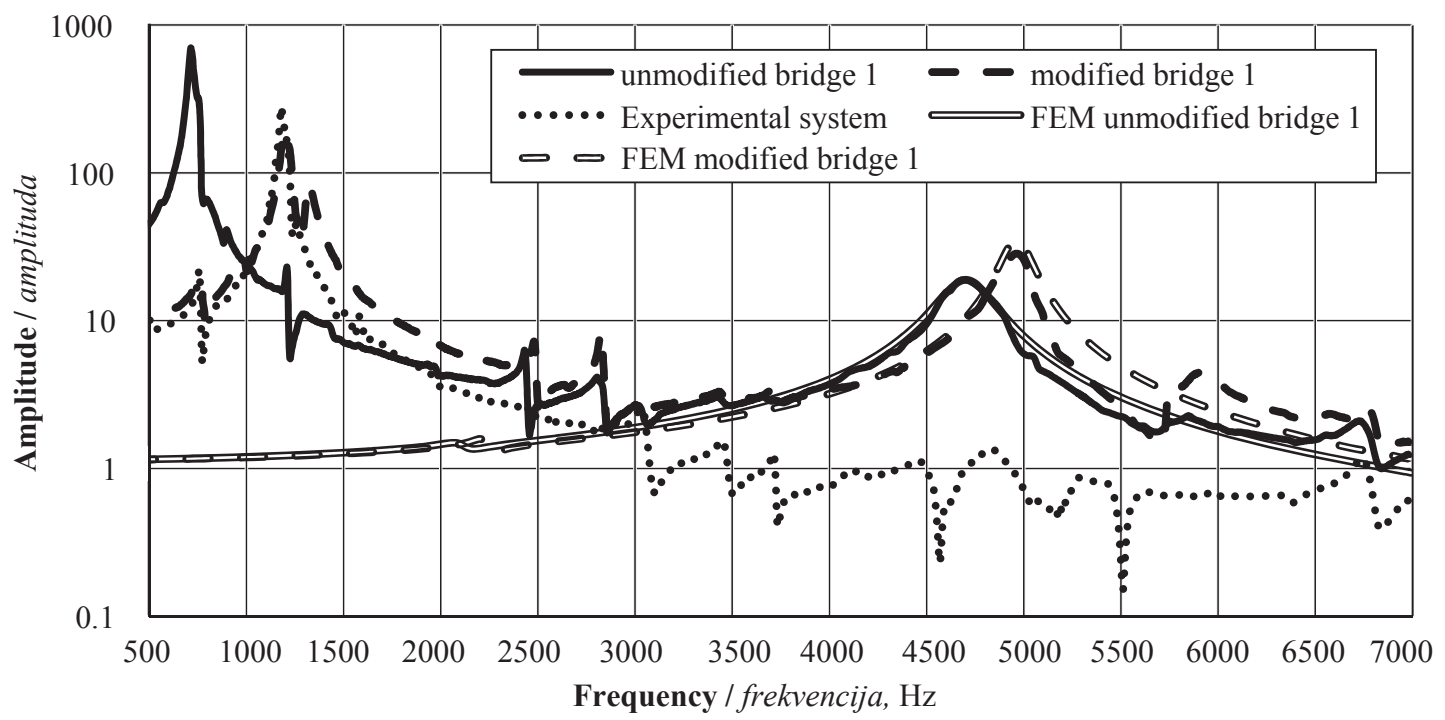

Figure 7 Measured and calculated transfer functions for violin bridge No. 1

Slika 7. Izmjerene i izračunane vrijednosti prijenosne funkcije mosta za violinu br. 1

show an increase of amplitude in the resonant frequency found for bridge No. 1 at $4720 \mathrm{~Hz}$ and increases with modification to $4950 \mathrm{~Hz}$. At bridge No. 2, which is already partly shaped and adapted for the violin, the resonant frequency increased from $3760 \mathrm{~Hz}$ to 3970 $\mathrm{Hz}$, as well as for bridge No. 3, where the resonant frequency increased from $4880 \mathrm{~Hz}$ to $5090 \mathrm{~Hz}$. In addition to the increase in the resonant frequencies, the images also show an increase in the amplitude of the modified bridges, which coincides with a decrease in the damping. In addition to an amplitude increase at the mentioned frequencies, the amplitudes of the transfer functions are also increased at frequencies from 500 to $1500 \mathrm{~Hz}$, which are due to the transfer function of the experimental system, and therefore should not be taken into account. The images show that the experimental system has the first resonant frequency with the highest vibration amplitude at $1180 \mathrm{~Hz}$, and additional resonant frequencies at higher values but with significantly smaller amplitudes.
To get the representative vibration modes, only bridge No. 1 was modelled with the finite element method, using the data from Table 2. Figure 10 shows the vibration modes of bridge No. 1 together with the associated natural frequencies. The most important vibration modes for a violin are \#3, known as the "rocking" mode, and vibration mode \#6, known as the "bouncing" mode, where the calculated natural frequency for unmodified and modified bridges amounted to $4705 \mathrm{~Hz}$ and $4960 \mathrm{~Hz}$, respectively. In addition to the modal analysis, a harmonic analysis was performed, by which a transfer function was calculated for bridge No. 1, whose values are shown in Figure 7. Very good agreement between the measured and calculated transfer functions can be seen between $3000 \mathrm{~Hz}$ and $7000 \mathrm{~Hz}$ for both unmodified and modified bridges, which deteriorates at frequencies below $3000 \mathrm{~Hz}$, since the measured transfer function has higher values due to the influence of the experimental system. If the measured transfer function of the bridge were to be correct-

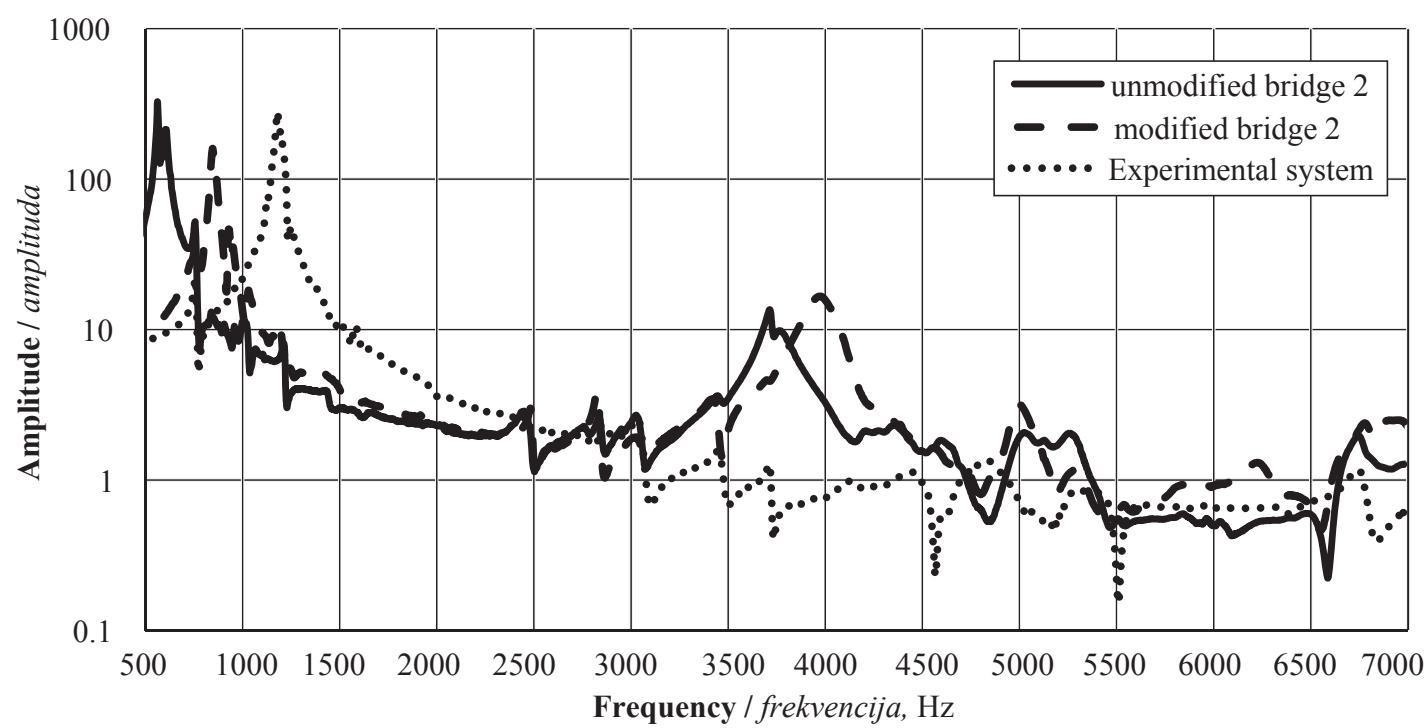

Figure 8 Measured transfer functions for violin bridge No. 2

Slika 8. Izmjerene vrijednosti prijenosne funkcije mosta za violinu br. 2 


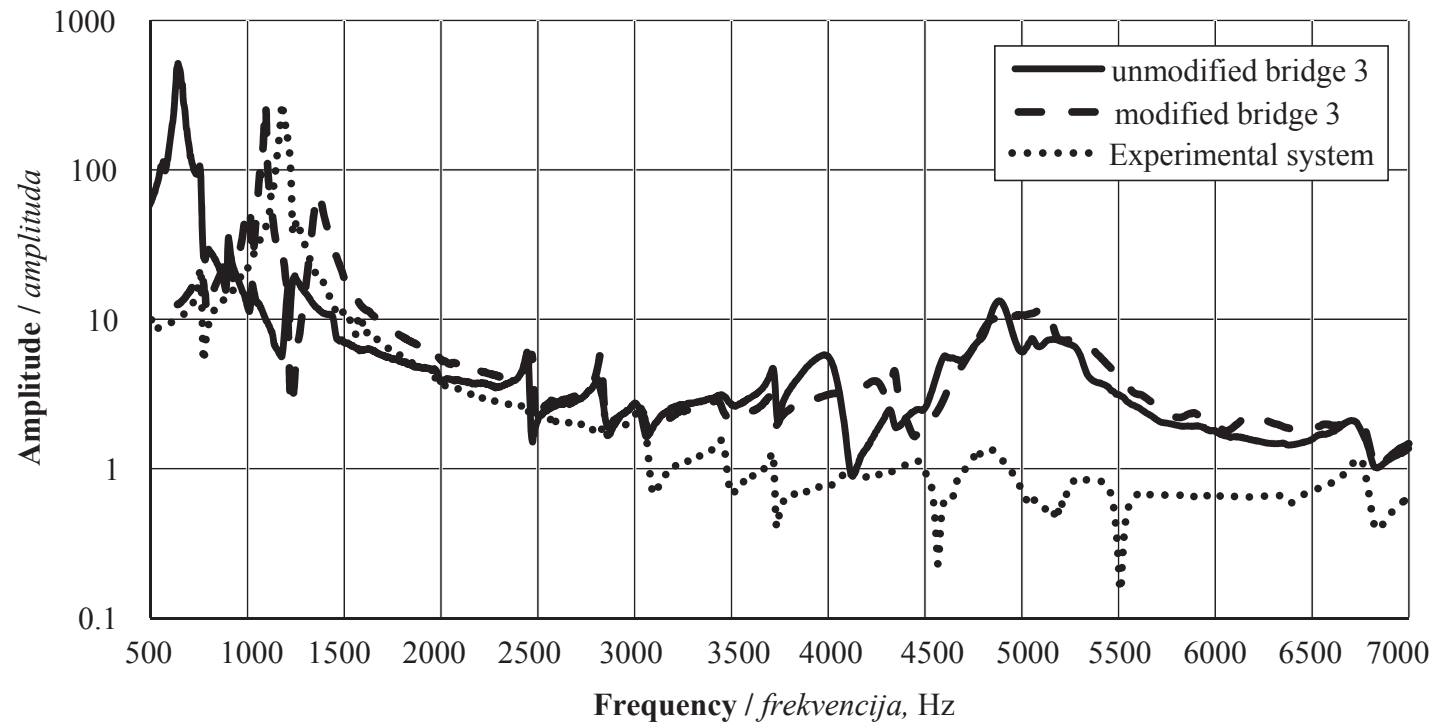

Figure 9 Measured transfer functions for violin bridge No. 3

Slika 9. Izmjerene vrijednosti prijenosne funkcije mosta za violinu br. 3

ed considering the experimental system transfer function, the agreement would be better at lower frequencies, too. The calculated transfer function of the bridge, in addition to a pronounced increase in amplitudes at $4720 \mathrm{~Hz}$ and $4950 \mathrm{~Hz}$, also has a slight in- crease in amplitudes at frequencies of $2060 \mathrm{~Hz}$ and $2200 \mathrm{~Hz}$, which are the natural frequencies of the rocking oscillation mode, and, due to its low vibration amplitude, are not evident in the measured transfer functions.

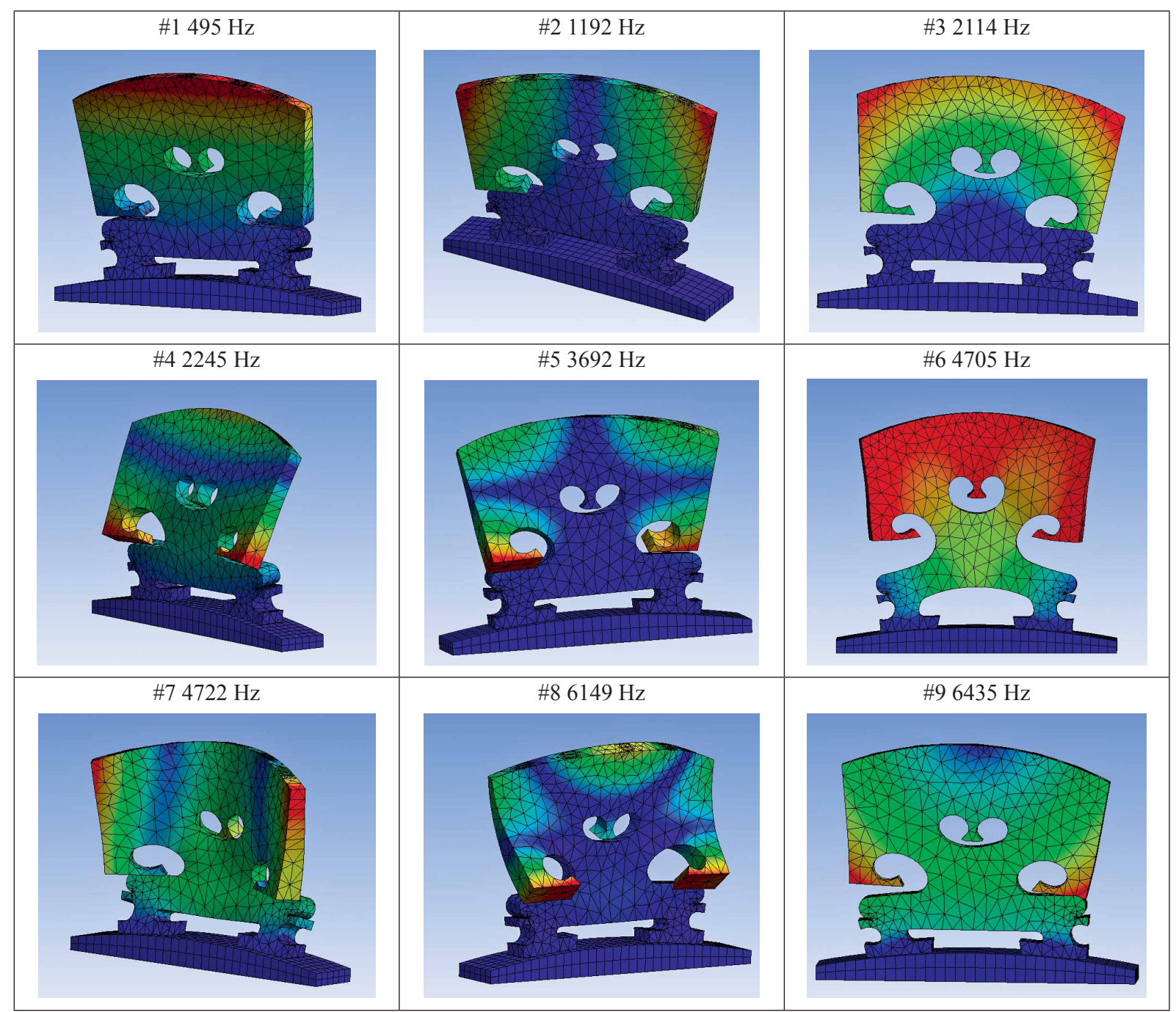

Figure 10 Vibration modes and corresponding natural frequencies of unmodified violin bridge No. 1 Slika 10. Načini vibracija i odgovarajuće prirodne frekvencije nemodificiranog mosta za violinu br. 1 


\section{CONCLUSIONS}

\section{ZAKLJUČAK}

From the analysis of the violin bridges, whereby the transfer functions were measured and calculated, it can be confirmed that thermal modification of wood affects the transfer function of violin bridges. Since the modulus of elasticity and shear modulus increase and the density decreases with modification, the natural frequencies increase accordingly, which means that the frequency range of the forces transferred by the bridge from the strings to the violin body increases. In addition, the modification also reduces the damping factors of the material, which helps to increase the amplitudes at the resonant frequencies of the bridges. The research thus confirmed that thermal modification is reasonable when the transmitted frequency range is to be increased and bridge damping is to be minimized. It is also reasonable to use the finite element method to calculate the transfer function and the natural frequencies of the bridge, since the study showed very good agreement between the calculated and measured values.

\section{Acknowledgements - Zahvala}

The authors acknowledge the support of the Slovenian Research Agency within the framework of programs P2-0182 and P4-0015.

\section{REFERENCES}

5. LITERATURA

1. Aditanoyo, T.; Prasetiyo, I.; Putra, I. B. A., 2017: Study on Vibro-acoustics Characteristics of Bamboo-based Violin. Procedia Engineering, 170: 286-292. https://doi.org/10.1016/j.proeng.2017.03.029.

2. Bissinger, G., 2004: The role of radiation damping in violin sound. Acoustics Research Letters Online-Arlo, 5 (3): 82-87. https://doi.org/10.1121/1.1675811.

3. Bissinger, G., 2006: The violin bridge as filter. Journal of the Acoustical Society of America, 120 (1): 482-491. https://doi.org/10.1121/1.2207576.

4. Bissinger, G., 2008: Structural acoustics of good and bad violins. Journal of the Acoustical Society of America, 124(3): 1764-1773. https://doi.org/10.1121/1.2956478.

5. Brancheriau, L.; Bailleres, H., 2002: Natural vibration analysis of clear wooden beams: a theoretical review. Wood Science and Technology, 36: 347-365. https://doi.org/10.1007/s00226-002-0143-7.

6. Dujourdy, H.; Ablitzer, F.; Cabaret, J.; Gautier, F., 2019: Force measurements at the bridge of a string instrument from acceleration measurements on the soundboard. Proceedings of the $26^{\text {th }}$ International Congress on Sound and Vibration, ICSV 2019.

7. Gough, C., 2018: The violin bridge-island input filter. Journal of the Acoustical Society of America, 143 (1): 1-12. https://doi.org/10.1121/1.5019474.

8. Jansson, E. V.; Barczewski, R.; Kabała, A., 2016: On the violin bridge hill - Comparison of experimental testing and FEM. Vibrations in Physical Systems, 27: 151-160.

9. Kabała, A.; Niewczyk, B.; Gapiński, B., 2018: Violin bridge vibrations - FEM. Vibrations in Physical Systems, 29: $1-7$.
10. Kollmann, F. F. P., 1975: Principles of wood science and technology. Berlin, Heidelberg, New York, Springer-Verlag.

11. Maia, N. M. M.; Silva, J. M. M., 1998: Theoretical and experimental modal analysis. Hertfordshire, Research Studies Press.

12. Matsutani, A., 2017: Photoelastic observation of violin bridge. Toraibarojisuto/Journal of Japanese Society of Tribologists, 62 (10): 617-622. https://doi.org/10.1143/JJAP.41.6291.

13. Matsutani, A., 2018: Experimental demonstration on air cavity mode of violin using holed sheets of paper. Physics Education, 53 (2): 1-6.

14. Ravina, E., 2017: Low-cost experimental assessment of forces in the contact bridge-soundboard of stringed musical instruments. Mechanisms and Machine Science, 47: 459-466. https://doi.org/10.1007/978-3-319-48375-7 49.

15. Rep, G.; Pohleven, F.; Košmerl, S., 2012: Development of the industrial kiln for thermal wood modification by a procedure with an initial vacuum and commercialisation of modified Silvapro wood. In: Proceedings of $6^{\text {th }}$ European conference on wood modification. Jones, D.; Militz, H.; Petrič, M.; Pohleven, F.; Humar, M.; Pavlič, M. (eds.). Biotechnical Faculty, Ljubljna, Slovenia, pp. 1320.

16. Rossing, T. D., 2010: The science of string instruments. New York, Springer

17. Setragno, F.; Zanoni, M.; Antonacci, F.; Rovetta, T.; Invernizzi, C., 2017: Feature-based analysis of the impact of ground coat and varnish on violin tone qualities. Acta Acustica united with Acustica, 103 (1): 80-93. https://doi.org/10.3813/AAA.919035.

18. Tai, H. C.; Shen, Y. P.; Lin, J. H.; Chung, D. T., 2018: Acoustic evolution of old Italian violins from Amati to Stradivari. Proceedings of the National Academy of Sciences of the United States of America, 115 (23): 59265931. https://doi.org/10.1073/pnas.1800666115.

19. Welzbacher, C. R.; Scheiding, W., 2011: Implementation of a Quality Assurance System for thermally modified timber (TMT) by the Association of Central European TMT-Producers. The International Research Group on Wood Protection, IRG/WP 11-40558 Stockholm, Sweden.

20. Woodhouse, J., 2014: The acoustics of the violin: a review. Reports on Progress in Physics, 77 (11): 1-42. https://doi.org/10.1088/0034-4885/77/11/115901.

21. Woodhouse, J., 2005: On the "bridge hill" of the violin. Acta Acustica united with Acustica, 91 (1): 155-165.

22. Zhang, C. Z.; Zhang, G. M.; Ye, B. Y.; Liang, L. D., 2013: Violin Bridge Mobility Analysis under In-Plane Excitation. Sensors, 13 (11): 15290-15306. https://doi.org/10.3390/s131115290.

\section{Corresponding address:}

Assist. Prof. MIRAN MERHAR, PhD

University of Ljubljana

Biotechnical Faculty

Department of Wood Science and Technology

Jamnikarjeva 101, 1000 Ljubljana, SLOVENIA

e-mail: Miran.Merhar@bf.uni-lj.si 